\title{
Occurrence of Infectious Laryngotracheitis Virus (Iltv) in 2009-2013 in the State of São Paulo - Brazil
}

http://dx.doi.org/10.1590/1516-635x1701117-120

Technical Note

\section{-Author(s)}

Parra SHS

Nuñez LFN'

Astolfi-Ferreira CS

Ferreira JPI

Laboratory of Avian Diseases, Department of Pathology, School of Veterinary Medicine (FMVZ), University of São Paulo (USP).

\section{Mail Address}

Corresponding author e-mail address

A. J. Piantino Ferreira

Laboratory of Avian Diseases, Department of Pathology, School of Veterinary

Medicine (FMVZ), University of São Paulo (USP), Av. Orlando M. Paiva, 87, 05508-

270, São Paulo, SP, Brazil.

E-mail: ajpferr@usp.br

\section{-Keywords}

Infectious Laryngotracheitis, PCR, detection, trachea, trigeminal.

\section{ABSTRACT}

Infectious laryngotracheitis is a very important respiratory disease because it causes significant economic losses in the poultry industry. The target of ILTV infections is the respiratory system, and the main organ in which the virus remains latent is the trigeminal ganglia. However, the virus has demonstrated tropism for other organs as well. The present study was conducted to determine the presence of Infectious Laryngotracheitis Virus (ILTV) in the state of São Paulo. Samples submitted to LABOR- USP during the last four years (20092013) analyzed by a nested/PCR technique. Out of the 682 samples from layers tested for LTIV, $12.46 \%$ were positive, and derived from in both traditional (trachea and trigeminal ganglion) and untraditional (cecal tonsils, digestive tract and kidneys) organs utilized for ILTV diagnosis. The present work showed that ILTV is circulating in commercial layer flocks in São Paulo State, and that the LTIV is present in other organs in addition to the respiratory tract and trigeminal ganglion; however, it was not determined if the circulating virus is a vaccinal or field strain.

\section{INTRODUCTION}

Infectious laryngotracheitis (ILT) of birds is a highly contagious disease that primarily affects chickens, pheasants, and partridges, with hens as the primary host. Starlings, sparrows, crows, pigeons, and ducks seem to be resistant to the virus (Guy \& Garcla, 2008). The causative agent is a pneumotropic virus of the family Herpesviridae, genus Iltovirus. Taxonomically, this virus is classified as a Gallid herpesvirus 1 (Zhao et al., 2013). This disease is included in the list of mandatory notification of terrestrial and aquatic animal diseases of the OIE. Its notification to the Brazilian Official Service is also mandatory (http://www.oie.int/en/ animal-health-in-the-world/oie-listed-diseases-2014/).

Infectious laryngotracheitis was first described in 1925 (May \& Tittsler, 1925), and since then it has been reported in many countries, where it is endemic, especially in regions with intensive poultry production with large concentrations of birds and multi-age farms, such as in North America, China, Europe (especially in Poland), Australia, Africa, southwest Asia, New Zealand, and South America (Chacón \& Ferreira, 2009; Hidalgo, 2003). Viral transmission occurs via horizontal transfer, and the primary replication sites are in the tracheal mucosa and conjunctiva, where it can causes inflammation, mucoid or serous discharge, cough, and dyspnea. Poor egg production and weight gain are also observed (Coppo et al., 2013b).

The virus invades the trigeminal nerve during the lytic phase of infection, resulting in a latent infection that may be present during the entire life of the animal. Some stressors, such as the onset of lay and placement with other birds, may reactivate virus replication and 
shedding (Coppo et al., 2013a; Hughes et al., 1991; Hughes et al., 1989; Williams et al., 1992). Recent experimental studies indicate that the virus can also be detected in other organs, such as the heart, liver, spleen, lung, kidney, tongue, thymus, proventriculus, pancreas, duodenum, small intestine, large intestine, cecum, cecal tonsils, bursa, and brain (Oldoni et al., 2009; Wang et al., 2013; Zhao et al., 2013).

Molecular techniques, such as polymerase chain reaction $(P C R)$, have been successfully used for the detection of ILTV in respiratory and other organs (Chacón et al., 2007; Oldoni et al., 2009; Rodríguez Avila et al., 2007). Polymerase chain reaction presents high sensitivity and specificity for the detection of ILTV. It is able to detect viral DNA when other tests, such as histopathology and immunofluorescence, yield negative results (Crespo et al., 2007). Therefore, PCR provides a rapid diagnostic test that can aid in the differentiation between field and vaccinal strains (Clavijo \& Nagy, 1997).

The aim of this study was to evaluate the occurrence of the Infectious Laryngotracheitis Virus in samples submitted to the Laboratory of Avian Diseases of the School of Veterinary Medicine of the University of São Paulo between 2009-2013.

\section{MATERIALS AND METHODS}

\section{Sampling}

A total number of 682 samples from layer flocks from several cities of the state of São Paulo (Bastos, lacri, Tupã, Guapiaçu, Rancharia, Parapuã, Ibiúna) was analyzed. Out of the total number of samples, 337 derived from the trachea, 308 from the trigeminal ganglia, 11 from the lungs, six from the cecal tonsils, seven from the digestive tract, two from the liver, two from the spleen, one from the pancreas, and eight from the kidneys (Table 2).

\section{DNA extraction}

Total DNA was extracted according to the method of described by Chomczynski (1993). Briefly, samples were homogenized in sufficient $0.01 \mathrm{M}$ phosphate buffered saline (PBS; pH 7.4) to yield a $10 \%(\mathrm{w} / \mathrm{v})$ suspension, and clarified at $3000 \times \mathrm{g}$ for $20 \mathrm{~min}$ at $4^{\circ} \mathrm{C}$. The supernatant was separated and an aliquot $(200 \mu \mathrm{L})$ incubated for $5 \mathrm{~min}$ at $37^{\circ} \mathrm{C}$ with $1000 \mu \mathrm{L}$ of phenol/guanidine thiocyanate solution. Chloroform $(200 \mu \mathrm{L})$ was then added to the solution, the mixture was centrifuged $\left(12,000 \times \mathrm{g}\right.$ for $15 \mathrm{~min}$ at $\left.4^{\circ} \mathrm{C}\right)$, propanol $(750 \mu \mathrm{L})$ was added, and the whole mixture was cooled at $-20^{\circ} \mathrm{C}$ for at least $2 \mathrm{~h}$. Precipitated DNA was collected by centrifugation $(12,000 \times \mathrm{g}$ for 20 min at $4^{\circ} \mathrm{C}$ ). Any DNA that remained adhered to the wall of the tube was rinsed off with $70 \%$ ethanol and the solvent was allowed to evaporate. The total DNA sample was dissolved in $30 \mu \mathrm{L}$ of Tris-EDTA buffer.

\section{Viral Detection}

Viral detection was performed by a nested-PCR technique, which was oriented to the amplification of the gene that encodes protein E, as described by Chacón \& Ferreira (2008).

In a DNAse-free fresh microtube, $1 \times$ PCR Buffer, $1.25 \mathrm{mM}$ of each dNTP, $0.5 \mathrm{pmol}$ of each of the forward (GE1S) and reverse (GE2AS) primers (as described in table 1), $1.25 \cup$ of Platinum ${ }^{\circledR}$ Taq polymerase (Invitrogen by Life Technologies, Carlsbad, (A, USA), and $2.5 \mu \mathrm{L}$ of extracted DNA were added. DNA free ultrapure water was included to bring the volume to $25 \mu \mathrm{L}$. Amplification was performed in a Mastercycler ${ }^{\circledR}$ Nexus X1Eppendorf (Eppendorf AG, Hamburg, Germany). Thermal cycling consisted of an initial denaturation step of $3 \mathrm{~min}$ at $94^{\circ} \mathrm{C}$, followed by 45 cycles of denaturing at $94{ }^{\circ} \mathrm{C}$ for $1 \mathrm{~min}$, annealing at $58{ }^{\circ} \mathrm{C}$ for $30 \mathrm{~s}$, and extension at $72{ }^{\circ} \mathrm{C}$ for $45 \mathrm{~s}$. The end cycle was followed by an extension step at $72{ }^{\circ} \mathrm{C}$ for $10 \mathrm{~min}$. The second round of amplification (nested-PCR) was performed in a similar manner, although a second set of primers (GE3S forward and GE4AS reverse) was employed, as described in Table 1. The PCR products were visualized after separation by electrophoresis in an agarose gel (1.5\%) using Blue Green Dye (LGC, Sao Paulo, Brazil) to stain the DNA. The size of the amplified product was estimated using the 100 base pair DNA Ladder molecular size marker (Invitrogen).

Table 1 - Primers, nucleotide sequences, amplified products (in bp), and references used in the nested-PCR test.

\begin{tabular}{|c|c|c|c|c|c|}
\hline Virus & Reaction & Primer & Nucleotide Sequence $\left(5^{`}-3^{\prime}\right)$ & (bp) & Reference \\
\hline \multirow{2}{*}{$\begin{array}{l}\text { Infectious } \\
\text { Laryngotracheitis Virus }\end{array}$} & PCR & $\begin{array}{l}\text { GE1S } \\
\text { GE2AS }\end{array}$ & $\begin{array}{l}\text { CGTATACCATCCTACAGACGGCA } \\
\text { CGTACAATGGTTCGGTCTTGGA }\end{array}$ & 540 & \multirow{2}{*}{ (Chacón \& Ferreira, 2008) } \\
\hline & NESTED & $\begin{array}{l}\text { GE3S } \\
\text { GE4AS }\end{array}$ & $\begin{array}{l}\text { AGTCCTCTTATAGCCATCCCCA } \\
\text { CACCCCCGCGACGACGAAGT }\end{array}$ & 219 & \\
\hline
\end{tabular}


Table 2 - ILTV frecuency in the analyzed organs, as detected by nested-PCR.

\begin{tabular}{lccc}
\hline Organs analyzed & $\begin{array}{c}\text { Positive } \\
\text { Samples }\end{array}$ & $\begin{array}{c}\text { Percentage } \\
(\%) \text { per organ } \\
\text { analyzed }\end{array}$ & $\begin{array}{c}\text { Total Samples } \\
\text { Analyzed }(\mathrm{n})\end{array}$ \\
\hline Trachea & $56 / 337$ & 8.21 & 337 \\
\hline Trigeminal ganglia & $19 / 308$ & 2.79 & 308 \\
\hline Lungs & $7 / 11$ & 1.03 & 11 \\
\hline Cecal tonsils & $1 / 6$ & 0.15 & 6 \\
\hline Digestive tract & $1 / 7$ & 0.15 & 7 \\
\hline Liver & $0 / 2$ & - & 2 \\
\hline Spleen & $0 / 2$ & - & 2 \\
\hline Pancreas & $0 / 1$ & - & 1 \\
\hline Kidneys & $1 / 8$ & 0.15 & 8 \\
\hline Total & $85 / 682$ & 12.46 & 682
\end{tabular}

\section{RESULTS}

Using the nested-PCR technique, an amplified product of $219 \mathrm{bp}$ from analyzed samples was obtained (Figure 1). The nested-PCR technique did not amplify any product other than the expected size product. Positive results were obtained in 56/337 (16.6\%) of the tracheal samples, $19 / 308(6.1 \%)$ of trigeminal ganglia, $7 / 11(63.6 \%)$ of the lungs, $1 / 6$ (16.6) of the cecal tonsils, $1 / 7(14.3 \%)$ of the digestive tract, and $1 / 8$ $(12.5 \%)$ of the kidneys. Negative results were found in 2/2 livers, 2/2 spleens, and 1/1 pancreas. (Table 2). Out of the 682 samples analyzed for ILTV, $85(12.46 \%)$ samples were positive for ILTV and 597 (87.54\%) samples were negative. The highest number of ILTVpositive samples were trachea samples (56), which showed the highest percentage $(8.21 \%)$ of positivity for ILTV. On the other hand, liver, spleen, and pancreas samples were negative for ILTV (Table 3).

Table 3 - ILTV distribution in the 682 analyzed samples from different organs of layers in São Paulo State.

\begin{tabular}{lccc}
\hline $\begin{array}{l}\text { Organs } \\
\text { analyzed }\end{array}$ & Positive Samples & $\begin{array}{c}\text { Negative } \\
\text { Samples }\end{array}$ & $\begin{array}{c}\text { Total Samples } \\
\text { Analyzed }(\mathrm{n})\end{array}$ \\
\hline Trachea & $56(8.21 \%)$ & $281(41.20 \%)$ & $337(49.41 \%)$ \\
\hline $\begin{array}{l}\text { Trigeminal } \\
\text { ganglia }\end{array}$ & $19(2.79 \%)$ & $289(42.38 \%)$ & $308(45.16 \%)$ \\
\hline Lungs & $7(1.03 \%)$ & $4(0.59 \%)$ & $11(1.61 \%)$ \\
\hline Cecal tonsils & $1(0.15 \%)$ & $5(0.73 \%)$ & $6(0.88 \%)$ \\
\hline Digestive tract & $1(0.15 \%)$ & $6(0.88 \%)$ & $7(1.03 \%)$ \\
\hline Liver & 0 & $2(0.29 \%)$ & $2(0.29 \%)$ \\
\hline Spleen & 0 & $2(0.29 \%)$ & $2(0.29 \%)$ \\
\hline Pancreas & $1(0.15 \%)$ & $7(1.03 \%)$ & $8(1.17 \%)$ \\
\hline Kidneys & $85(12.46 \%)$ & $597(87.54 \%)$ & $682(100 \%)$ \\
\hline Total & & $1(0.15 \%)$ & $1(1.15 \%)$ \\
\hline
\end{tabular}

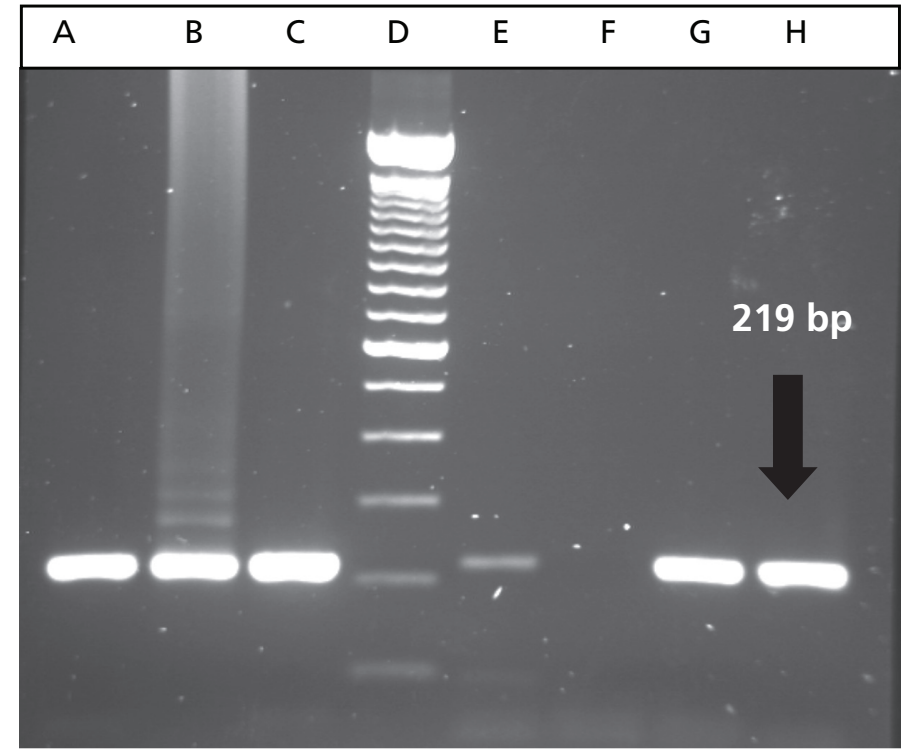

Figure 1 - Nested-PCR product (219 bp) of the partial amplification of ILTV glycoprotein E gene. Lanes A, B, E, G, H: tested samples. Lane C: positive control. Lane F: negative control, and Lane D: Molecular size marker (100 bp).

\section{DISCUSSION AND CONCLUSION}

Infectious laryngotracheitis (ILT) is a disease that causes singnificant economic losses due to increased mortality and reduced growth rates and egg production (Guy \& Garcla, 2008). The target of ILTV infections is the respiratory system, specifically the epithelium of the trachea and larynx, although the sinuses and lungs may also be infected. The target site of infection largely depends on the route of inoculation (Bagust \& Johnson, 1995). In the present study, ILTV was detected in seven (63.6\%) lung samples and $57(16.6 \%)$ tracheal samples, showing a wide viral distribution and strong tropism for the respiratory organs, despite its detection in the intestines, cecal tonsils, and trigeminal ganglia.

The main organ in which ILTV is latent is the trigeminal ganglia, possible because the trigeminal nerve is the main enervator of the upper respiratory tract, tongue and eyes, and the distal part is involved in the innervation of the trachea (Bagust \& Johnson, 1995; Bagust, 1986; Williams et al., 1992). The presence of ILTV was detected in 19 of the evaluated trigeminal ganglia samples, showing that the virus became latent in a few chickens.

Our study indicates that viral detection was detected in higher numbers in the lungs, trachea, and trigeminal ganglia. This is consistent with previously reported results, indicating that greater viral replication was detected in the respiratory organs (Oldoni et al., 2009; Rodríguez Avila et al., 2007). However, other organs, such as the lungs, cecal tonsils, digestive tract, 
and kidneys were also positive. These findings are in agreement with other studies (Wang et al., 2013; Zhao et al., 2013), in which viral DNA was detected and quantified in the heart, liver, spleen, kidneys, tongue, thymus, proventriculus, duodenum, pancreas, small intestine, large intestine, cecum, cecal tonsils, bursa, and brain. These results indicate that circulating ILTV strains may show tropism for other organs in addition to the respiratory system. Further studies, using ILTVspecific immuno-histochemical techniques should be performed in order to confirm such finding.

Five hundred ninety-seven (597) out of 682 (87.5\%) samples were negative by the aforementioned molecular tests, implying partial success of the vaccination program regarding reducing viral activity. Indeed, the positive samples $(12.46 \%)$ revealed viral presence in healthy chickens. In addition, viral presence could also mean that a field strain is circulating among layer flocks. This is suggested by the detection of ILTV in uncommon organs and indicates that the pathogenesis of the disease is not well understood. Several studies using molecular techniques, such as PCR for detection of ILTV (Chacón et al., 2007; Chacón \& Ferreira, 2008; Clavijo \& Nagy, 1997; Crespo et al., 2007), prove that these techniques are very sensitive and specific. In the present study, a reaction of nested-PCR, oriented to the amplification of part of the gene encoding glycoprotein E, was successfully used to investigate the presence and tissue location of ILTV in layer chickens.

The results of this study demonstrate that ILTV is circulating in laying flocks reared in São Paulo state; however, it is unknown if the circulating virus is a vaccinal or a field-derived strain. Further studies should focus on differentiating the nature of these strains. Additionally, it must be noted that, at the time of diagnosis, organs other than those of the respiratory system presented ILTV infection.

\section{REFERENCES}

Bagust TJ. Laryngotracheitis (Gallid-1) herpesvirus infection in the chicken. 4. Latency establishment by wild and vaccine strains of ILT virus. Avian Pathology 1986;15: 581-595.

Bagust TJ, Johnson MA. Avian infectious laryngotracheitis: Virus-host interactions in relation to prospects for eradication. Avian Pathology 1995;24: 373-391.

Chacón JL, Brandao PE, Villareal LY, Gama NM, Ferreira AJP. Survey of Infectious Laryngotracheitis Outbreak in Layer Hens and Differential Diagnosis with other Respiratory Pathogens. Brazilian Journal of Poultry Science 2007; 9: 61-67.

Chacón JL, Ferreira AJP. Development and validation of nested-PCR for the diagnosis of clinical and subclinical infectious laryngotracheitis. Journal of Virological Methods 2008;151: 188-193.
Chacón JL, Ferreira APJ. Differentiation of field isolates and vaccine strains of infectious laryngotracheitis virus by DNA sequencing. Vaccine 2009;27:6731-6738.

Chomczynski P. A reagent for the single-step simultaneus isolation of RNA, DNA and protein for the cell and tissues samples. Biotechniques 1993;15: 532-536

Clavijo A, Nagy E. Differentiation of Infectious Laryngotracheitis Virus Strains by Polymerase Chain Reaction. Avian Diseases 1997;41:241246.

Coppo MJC, Hartley CA, Devlin JM. Immune responses to infectious laryngotracheitis virus. Developmental and Comparative Immunology 2013a;41:454-462.

Coppo MJC, Noormohammadi AH, Browning GF, Devlin JM. Challenges and recent advancements in infectious laryngotracheitis virus vaccines. Avian Pathology 2013b;42:195-205.

Crespo R, Woolcock PR, Chin RP, Shivaprasad HL, Garcia, M. Comparison of Diagnostics Techniques in an Outbreak of Infectious Laryngotracheitis from Meat Chickens. Avian Diseases 2007;51:858-862.

Guy JS, Garcia M. Laryngotraqueitis. In: Saif YM, Glisson JR, Fadly AM, Mcdougald LR, Nolan LK, Swayne DE, editors. Diseases of poultry. 12thed. Ames: lowa State University Press; 2008. p.137-152.

Hidalgo, H. Infectious Laryngotracheitis: A Review. Brazilian Journal of Poultry Science 2003; 5:157-168.

Hughes CS, Gaskell RM, Jordan FTW, Bradbury JM, Jones RC. Effects of certain stress factors on the re-excretion of infectious laryngotracheitis virus from latently infected carrier birds. Reserch in Veterinary Science 1989; 46:274-276.

Hughes CS, Williams RM, Gaskell RM, Jordan FTW, Bradbury JM, Bennett $M$, Jones RC. Latency reactivation of infectious laryngotracheitis vaccine virus. Archives of Virology 1991; 121:213-218.

May HJ, Tittsler RP. Tracheo-laryngotracheitis in poultry. Journal of American Veterinarian Medical Association 1925;67:229-231.

Oldoni I, Rodríguez-Avila A, Riblet SM, Zavala G, García M. Pathogenicity and growth characteristics of selected infectious laryngotracheitis virus strains from the United States. Avian Pathology 2009;38:47-53.

Rodríguez-Avila A, Oldoni I, Riblet S, García M. Replication and Transmission of Live Attenuated Infectious Laryngotracheitis Virus (ILTV) Vaccines. Avian Diseases 2007;51:905-911.

Wang LG, Ma J, Xue CY, Wang W, Guo C, Chen F, Qin JP, Huang NH, Bi YZ, Cao YC. Dynamic distribution and tissue tropism of infectious laryngotracheitis virus in experimentally infected chickens. Archives of Virology 2013;158:659-666.

Williams RA, Bennett M, Bradbury J M, Gaskell RM, Jones RC, Jordan FTW. Demonstration of sites of latency of infectious laryngotracheitis virus using the polymerase chain reaction. Journal of General Virology 1992;73:2415-2420

Zhao Y, Kong C, Cui X, Cui H, Shi X, Zhang X, Hu S, Hao L, Wang Y. Detection of infectious laryngotracheitis virus by real-time PCR in naturally and experimentally infected chickens. PLOS ONE 2013;8:110. 
In the article entitled Litter Characteristics and Pododermatitis Incidence in Broilers Fed a SorghumBased Diet published in the Revista Brasileira de Ciência Avícolas/Brazilian Journal of Poultry Science, v16 (3): 291-295, in page 291 where it was written

\section{- Keywords}

Turkey, Enteritis, Viruses, Poults, Diagnosis,

calcium, environmental impact, phosphorus

the correct form is

\section{-Keywords}

Calcium, environmental impact, phosphorus.

http://dx.doi.org/10.1590/1516-635x1603121-121 
